症例

胃穹窡部に発生し十二指腸脱出をきたした過形成性ポリープの 1 例

$$
\text { 千葉県がんセンター消化器外科 }
$$

$\begin{array}{lllllll}\text { 星 } & \text { 野 } & \text { 敢 } & \text { 永 } & \text { 田松夫 } & \text { 渡 辺 } & \text { 男 } \\ \text { 山 } & \text { 本 } & \text { 宏 } & \text { 田 崎 } & \text { 健太郎 } & \text { 渡 辺 } & \text { 敏 }\end{array}$

症例は50歳，女性．心窩部不快感，黒色便出現にて近医受診となった１998年 8 月11 日上部消化管内視鏡検㚗施行され，易出血性の腫慯を認めたため，同 8 月14日精㚗加療 目的にて当科紹介入院となった. 上部消化管造影検查・内視鏡検査にて, 胃穹竉部後壁 に基部を有する腫溜性病変が，幽門輪を越えて十二指腸球部に脱出しており，腫溜は体 外からの圧迫により胃内に容易に還納された．また前庭部後壁に O-IIc 病変を認めた. 生検の結果はそれぞれ，過形成性ポリープ(group II) と，低分化腺癌であったため, 1998 年 8 月27日，幽門側胃切除術およびポリープ切除術を施行した.

胃内の腫瘤が十二指腸に脱出する報告は多数認めるが，自験例のように胃の上部に発 生した腫瘤が十二指腸に脱出することは比較的稀であり，若干の文献的考察を加えて報 告した。

卖引用語：胃腫場, 過形成性ポリープ，十二指腸脱出

はじめに

胃腫場の十二指腸脱出例の報告は多数みるが，その 多くが前庭部や幽門輪上に発生した上皮性腫湯であ り, 胃の上部に発生した腫瘍が脱出することは比較的 稀である.今回われわれは, 胃穹慥部より発生した過 形成性ポリープが十二指腸に脱出した 1 例を経験した ので，若干の文献的考察を加え報告する．

$$
\text { 症例 }
$$

患者：50歳, 女性.

主訴：心简部不快感，負血。

既往歴：特記すべきことなし。

現病歴：1998年 7 月より心窩部不快感, 黒色便が出 現したため, 同 7 月28日近医を受診した。胃潰場が疑 われ, proton pomp inhibiter を投与されるも症状改善 せず，8月11日同院にて，上部消化管内視鏡検査施行 したところ, 前庭部に易出血性の腫锡を認めた。精查 加療目的にて 8 月14日当科に紹介された．初診時の血 液検査にて高度の筫血を認めたため, 同日緊急入院と なった.

2002 年 6 月 18 日受付 2002 年 8 月 19 日採用

〈所属施設住所〉

₹260-8717 千葉市中央区仁戸名町666-2
入院時現症：体格・栄養は中等度て, 眼瞼結膜に貣 血を認めるも，眼球結膜に黄疸はなかった，腹部は平 坦・軟で圧痛も諗めなかった。

入院時血液検查 : $\mathrm{Hb} 6.9 \mathrm{~g} / \mathrm{dl}, \mathrm{Ht} 21.3 \%$ と高度の 貧血を認めたが, 肝機能, 留機能など血液生化学検查 では異常所見はなかった。 AFP, CEA, CA19-9はとも に正常範囲内であった（表 1 ).

上部消化管造影検查：胃穹窒部後壁に基部を有する $40 \times 35 \mathrm{~mm}$ の腫瘤性病変が，幽門輪を越えて十二指腸 球部に脱出していた，腫瘤は体外からの圧迫により胃 内に容易に還納された（図 $1 \mathbf{a} ， \mathbf{b}$ ). 更に前庭部後 壁にO-IIc 病変が描出された（図 $1 \mathrm{c}$ ).

腹部造影 CT 検查：胃上部後壁に内腔に突出する直

表 1 血液 - 生化学検查

\begin{tabular}{lclc}
\hline WBC & $6.200 / \mathrm{mm}^{3}$ & TP & $5.9 \mathrm{~g} / \mathrm{dl}$ \\
$\mathrm{Hb}$ & $6.7 \mathrm{~g} / \mathrm{d}$ & $\mathrm{Alb}$ & $3.7 \mathrm{~g} / \mathrm{dl}$ \\
$\mathrm{Ht}$ & $21.3 \%$ & BUN & $14 \mathrm{mg} / \mathrm{dl}$ \\
$\mathrm{Plt}$ & $33.5 \times 10^{4} / \mathrm{mm}^{3}$ & Cre & $0.4 \mathrm{~g} / \mathrm{dl}$ \\
T.bil & $0.3 \mathrm{mg} / \mathrm{dl}$ & CRP & $0.1 \mathrm{mg} / \mathrm{dl}$ \\
$\mathrm{GOT}$ & $10 \mathrm{IU} / \mathrm{L}$ & CEA & $3.5 \mathrm{ng} / \mathrm{ml}$ \\
$\mathrm{GPT}$ & $8 \mathrm{IU} / \mathrm{L}$ & CA19-9 & $2 \mathrm{IU} / \mathrm{ml}$ \\
$\mathrm{LDH}$ & $156 \mathrm{IU} / \mathrm{L}$ & AFP & $1 \mathrm{ng} / \mathrm{ml}$ \\
GTP & $11 \mathrm{IU} / \mathrm{L}$ & & \\
\hline
\end{tabular}




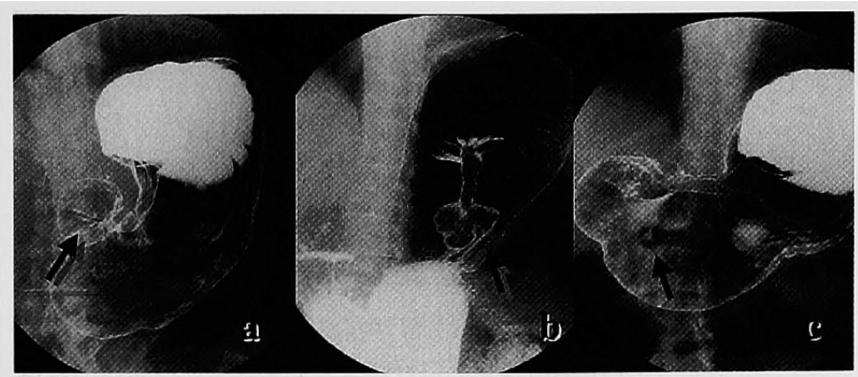

図 1 上部消化管造影検查：a）胃管登部後壁に基部を有する腫瘤性 病変が，幽門輪を越えて十二指腸球部に脱出していた (矢印)．b) 腫瘤は体外からの圧迫により胃内に容易に還納された (矢印)。 c) 前庭部後壁に O-IIc 病変が描出された（矢印）。

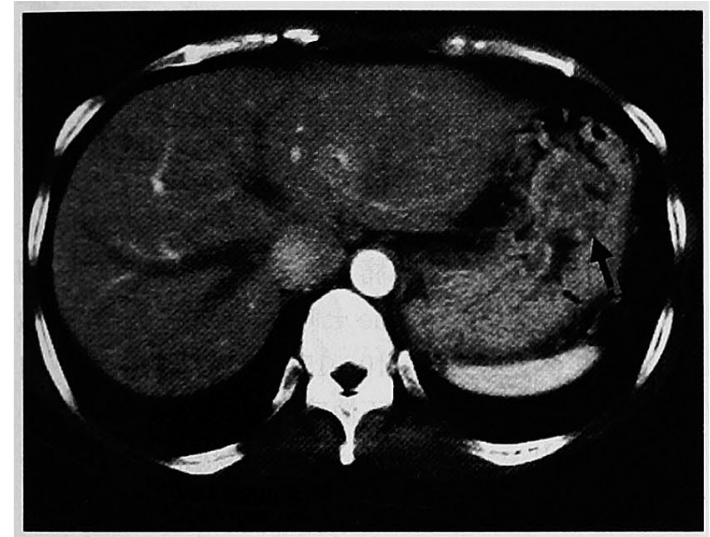

図 2 腹部造影 $\mathrm{CT}$ ：胃上部後壁に内腔に突出する腫瘤 を認めた。

径30mm の腫瘤認めた。腫瘤は造影 CTにて enhance されたが, 内部に一部 low density な領域も認めた。 明らかなリンパ節転移，肝転移の所見は認めなかった (図 2).

上部消化管内視鏡検查所見：胃穹窐部後壁に基部を 有し長い茎を持った腫瘤が，幽門輪を越え十二指腸球

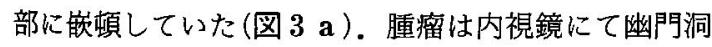
部を伸展することで容易に胃内に還納された。腫瘤よ りの明らかな出血は認めなかった(図 $\mathbf{3} \mathbf{b}$ )。 また, 前 庭部後壁に O-IIc 型の病変を認めた (図 $3 \mathbf{c}$ ). 生検の 結果はそれぞれ，過形成性ポリープ(group II) と，低 分化腺癌であった。

以上の諸検査にて胃穹䆙部より発生した過形成性ポ リープおよび前庭部の早期胃癌の診断にて1998年 8 月 27日開腹手術を施行した。

手術所見 : 上腹部正中切開にて開腹した。肝転移・
腹膜播種の所見を認めず, 腹腔洗浄細胞猃は陰性であ った．胃穹滗部の過形成性ポリープは胃内に触知可能 であった. 早期胃癌に対し型のごとくD 2 郭清を伴う 幽門側胃切除術を施行したが，ペッツにて胃の口側部 を切除するに先立ち, 切除側の胃の大彎側を切開し, 胃の内腔を観察した．過形成性ポリープを引き出し， 胃穹蕯部の根部を確認, ポリープ側より $2 \mathrm{~cm}$ の部位 にて茎を結森切除し (図 4), その後, 胃を $2 / 3$ 切除と して, Billroth I 法にて 2 層にて吻合を行った。術式と してポリープのみであれば内視鏡的切除も可能であっ たが，胃癌を併発していたため開腹手術を行った。ま た胃癌に関しては組織型が低分化腺癌で, 深達度も SM 程度と考えられ定型的な幽門側胃切除術を施行し た.

摘出標本：ポリープはカリフラワー様の腫瘤であ り，大きさ $45 \times 28 \times 20 \mathrm{~mm}$ で $15 \mathrm{~mm}$ の茎が合併切除さ れていた。潰㵿形成は認めなかった(図 $5 \mathbf{a}$ )。また前 庭部に $10 \times 8 \mathrm{~mm}$ の O-IIc 型早期胃癌を認めた（図 5 b).

病理所見：ポリープは, 腫瘍性の異型性は認めなか ったが, 内部に粘膜筇板が不規則に分岐しており，胃 底腺と腺窝上皮からなる腺管の配列は秩序性にそし く, 更に一部の腺管においては露腫様の拡張をきたし ていた (図6)。

前庭部の胃癌は低分化腺癌 (por 2) で, 組織学的進 行度は $\mathrm{pT} 1(\mathrm{~m}), \mathrm{pN} 0, \mathrm{H} 0, \mathrm{P} 0$, stage I a であ った.

術後に軽度吻合部狭窄を認めるも, 術後28日目に退 院となった. 現在, 初回手術後 3 年半経過するが, 再 発の兆候は認めず，健在である。 


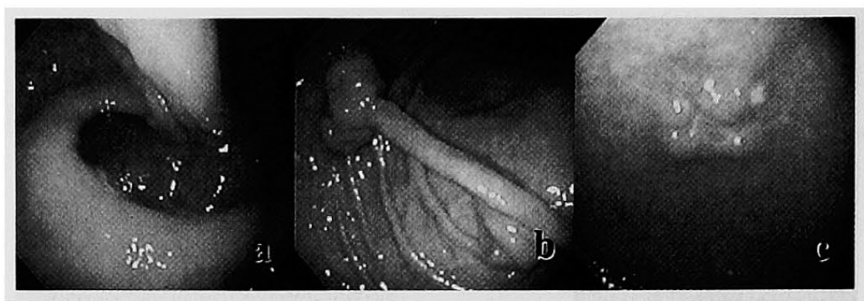

図 3 上部消化管内視鏡検査：a）胃穹薩部後壁に基部を有する腫瘤 が，幽門輪を越え十二指腸球部に嵌頓していた， b ) 腫瘤は内視鏡 にて幽門洞部を伸展することで容易に胃内に還納された。 c ) 前庭 部後壁に O-IIc 型の病変を認めた.

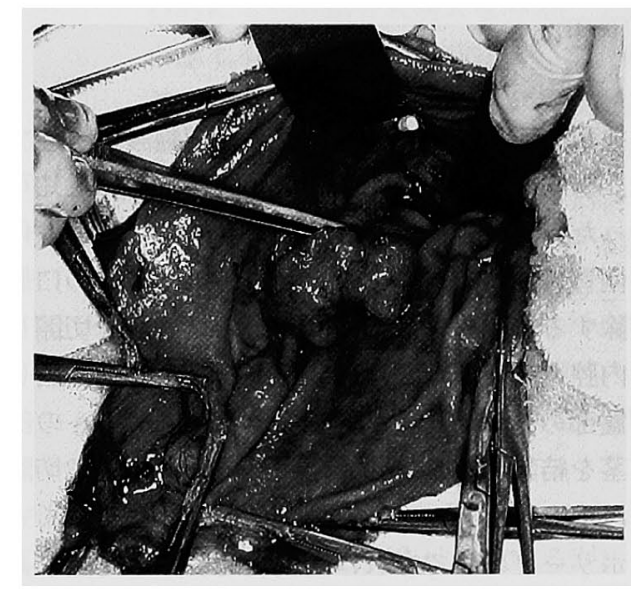

図 4 手術所見：胃の大彎側を切開し胃の内腔 を観察すると, 胃穹讉部を基部とする長い茎を 有したポリープが確認された。

\section{考察}

胃隆起性病変の十二指腸への脱出は本邦では1952年 の都留"の報告以来多数認める。しかしながら, 市成 らは本邦報告例100例を集計し, 胃の上部に発生した 腫揚の十二指腸への脱出は比較的稀であり，10\%に過 ぎなかったと報告している。

今回われわれは，胃の上部（胃体上部より口側）に 発生した腫锽が十二指腸へ脱出した本邦報告例を集計 したところ，20(例2) 21)を数え，本例が21例目であった (表 2 ).

年齢は50 76歳, 平均66歳と比較的高齢者に多かっ た。性別は男女比 $3: 7$ と女性に多い傾向がみら机た。 腫瘍の最大径は, $3.0 \sim 8.0 \mathrm{~cm}$, 平均 $6.6 \mathrm{~cm}$ であった。 病理組織学的には平滑筋腫が 8 例, 平滑筋肉腫 5 例, 神経鞙腫 3 例, 平滑筋脂肪肉腫, 平滑筋芽腫, 腺癌, アデノーマ, 過形成性ポリープがそれぞれ 1 例であっ た。非上皮性腫場が21例中18例（85.7\%）と大多数を

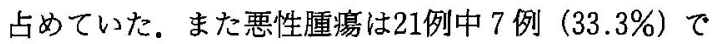
あった。市成ら 2)のざての占拠部位での集計では, 上 皮性腫場が75\%, 悪性腫場が87\%を占めたとしている. 胃上部腫場における十二指腸脱出例では, 非上皮性腫 湟が多いこと, 悪性腫湯の割合が少ないことが特幑と 考えられた.

胃内の腫瘤が，十二指腸に脱出して幽門を閉塞する ことにより激烈な心窩部痛・嘔気・嘔吐を反復する病 態を, ball valve syndrome と呼ぶが23), これらの特徽 的な症状を呈する症例は10〜15\%程度とされる ${ }^{24)}$. 自 験例においては，心窝部不快感を時折認めたのみで， 典型的な ball valve syndrome の症状は示さなかっ た.

腫漡の脱出機序については, 黒川 ${ }^{22}$ は, 胃の蜻動運動 により隆起性病変が異物の役割を果たし, 有茎性のも のでは茎が長くなって脱出し, 無茎性のものでも周团 粘膜の可動性が徐々に増大することで脱出するとして いる. 加えて石原ら゙は，胃の支持組織が脆弱な場合， 胃壁が緊張を失い, 更にそこに腫眗そのものの重量が 加わることによって結果的に十二指腸への脱出をきた すと報告している.今回のわれわれの集計においても， 比較的高㱓者が多いこと,腫瘍径が最小のものでも 3.0 $\mathrm{cm}$ であることからこの機序の妥当性を示唆している と考えられる.

画像的特徵としては, 上部消化管造影検査では, 小 彎の短縮や胃の著明な変型, 幽門へ向かう異常なレリ 一フ像，十二指腸内の腫瘤陰影が挙げられる4). また, 内視鏡検查では，特異なすう贈譬を含む索状物の幽門 内消失を認めるとされる4).われわれの症例において も, これらの画像的特徵を伴っていた.

本症例は胃穹薩部に発生した過形成性ポリープであ つたが, 胃前庭部に早期胃癌を伴っていた。 今回のわ れわれの検索においては，十二指腸に脱出をきたした 


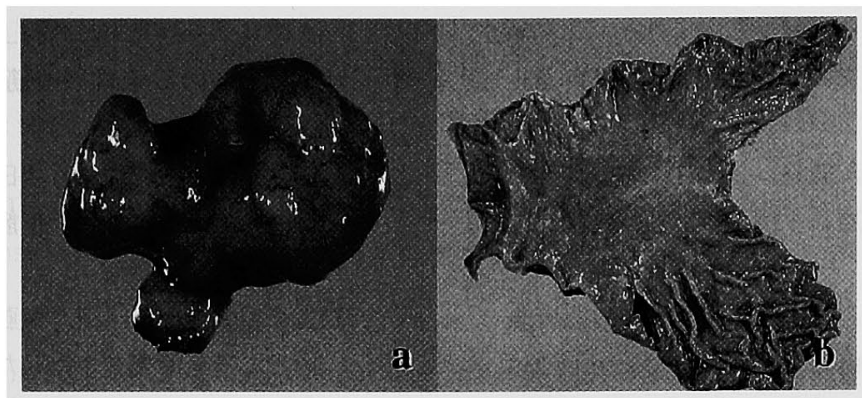

图 5 摘出標本：a) ポリープはカリフラワー様の腫瘦であり, 大き さは $45 \times 28 \times 20 \mathrm{~mm}$ であった， b ) 前庭部に $10 \times 8 \mathrm{~mm}$ の O-IIc 型 早期罢癌を認めた（矢印）.

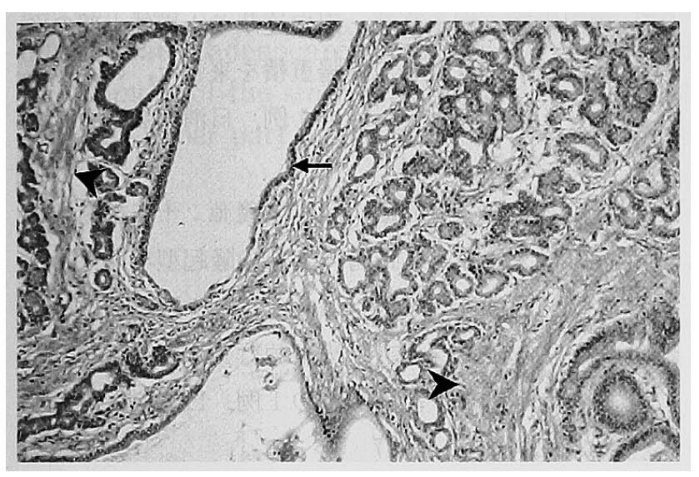

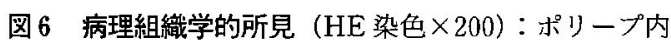
にて, 粘膜筋板が不規則に分岐しており(矢頭), 腺管

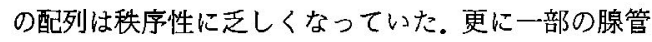
においては蕒腫様の㹡張をきたしていた（失印）。
腫瘤以外に胃癌を併発した報告は矢後ら ${ }^{199}$ のつの早 期胃癌を併発したとの報告をみるのみであり極めて稀 であった，本症例は，胃癌が存在したため幽門側胃切 除術およびポリープ切除術を施行したが, ポリープの みであれば内視鏡的ポリープ切除の適応だったと考え られる。

\section{結語}

胃穹箼部に発生した過形成性ポリープが十二指腸に 脱出した 1 例を経験したので, 若干の文献的考察を加 えて報告した。

表 2 胃上部（胃体上部より口側）腫瘍の十二指腸脱出本邦報告例

\begin{tabular}{|c|c|c|c|c|c|c|c|}
\hline NO. & 報告者 & 年 & 年齢 & 性別 & 部位 & 大きさ $(\mathrm{cm})$ & 病理 \\
\hline 1 & 古賀 & 1968 & 68 & 男 & 穹落部・前壁・大獎 & $7.5 \times 5.4 \times 5.0$ & 平滑筇腫 \\
\hline 2 & 井田 & 1970 & 54 & 女 & 体上部・後壁・大筧 & $5.0 \times 4.3 \times 4.0$ & 神経鞘腫 \\
\hline 3 & 久本 & 1975 & 76 & 女 & 穹䆺部・後壁 & $5.8 \times 5.5 \times 5.0$ & 平滑筋脂肪肉腫 \\
\hline 4 & 山城 & 1976 & 60 & 女 & 体上部・後壁 & $8.0 \times 6.0$ & 平滑筋肉腫 \\
\hline 5 & 西川 & 1977 & 63 & 女 & 穹墔部 & $6.0 \times 4.5 \times 4.0$ & 平猾筋腫 \\
\hline 6 & 小林 & 1979 & 68 & 女 & 管察部・前壁 & $5.5 \times 5.0 \times 4.5$ & 神経鞘腫 \\
\hline 7 & 石原 & 1981 & 74 & 女 & 体上部・小繁 & $8.0 \times 5.5 \times 5.5$ & 神経靬腫 \\
\hline 8 & 朔 & 1981 & 65 & 男 & 管篝部・前壁 & $7.0 \times 5.3 \times 5.0$ & 平滑筋腫 \\
\hline 9 & 石川 & 1981 & 72 & 女 & 体上部・前壁・大慜 & $7.0 \times 5.0 \times 3.0$ & 平滑筋腫 \\
\hline 10 & 布施 & 1983 & 55 & 女 & 体上部・大第 & 5.5 & 平滑筋腫 \\
\hline 11 & 大村 & 1986 & 58 & 男 & 体上部・前壁 & $4.3 \times 3.8 \times 4.0$ & 平滑筋芽腫 \\
\hline 12 & 西浦 & 1988 & 60 & 男 & 体上部・後壁 & $5.5 \times 4.5 \times 3.5$ & 平滑筋腫 \\
\hline 13 & 大下 & 1990 & 72 & 女 & 体上部 - 前壁 - 大䟺 & $4.5 \times 4.0 \times 3.5$ & 平滑筋肉腫 \\
\hline 14 & 神崎 & 1991 & 46 & 女 & 体上部・前壁 & $6.4 \times 5.8 \times 5.4$ & 平滑筋腫 \\
\hline 15 & 市成 & 1991 & 71 & 男 & 体上部・大䇾 & $3.5 \times 2.5 \times 2.0$ & アデノーマ \\
\hline 16 & 吉田 & 1993 & 77 & 男 & 体上部・後壁・大磷 & 3.0 & 腺癌 \\
\hline 17 & 善田 & 1994 & 72 & 女 & 体上部・後壁 & $6.4 \times 5.8 \times 4.4$ & 平滑筋腫 \\
\hline 18 & 知後 & 1997 & 82 & 男 & 管簅部・大繁 & $5.5 \times 5.5 \times 3.0$ & 平滑筋肉腫 \\
\hline 19 & 佐々木 & 1998 & 68 & 女 & 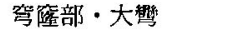 & $4.5 \times 4.5 \times 3.0$ & 平滑筋肉嗹 \\
\hline 20 & 高山 & 1999 & 65 & 女 & 穹落部 & $7.5 \times 6.5$ & 平滑筋肉腫 \\
\hline 21 & 自験例 & & 50 & 女 & 驾落部・後壁 & $4.5 \times 2.8 \times 2.0$ & 過形成性ポリーフ \\
\hline
\end{tabular}




\section{文献}

1) 都留昌人：胃ポリープの 1 例. 医療 $6: 61-63$, 1952

2）市成秀樹，井上正邦，関谷 亮他：十二指腸球部 に脱出した胃体部腺腫の1例. 日消外会誌 24 ： 2405-2408, 1991

3）古賀安彦，賀来正義，大里敬一：興味ある臨床像 を呈した胃粘膜下腫瘍の 1 例. Gastroenterol Endosc $10: 136-137,1968$

4）井田和徳，中島正継，赤坂裕三他：十二指腸への 脱出性胃腫瑒のX線像．臨放線 $15: 609-615$, 1970

5）久本 寛，米沢美枝子，牛島康栄他：胃穹稀部に 基を有し長期十二指腸に嵌頓した胃粘膜下腫堭の 1 例. 臨外 $30: 385-389,1975$

6）山城宗亮, 川手 稔, 宮城 靖他：十二指腸へ脱 出した胃上部腫瘍の1例. 日医放線会誌 36 : 1025,1976

7）西川晆彦，星島説夫，岩永幸夫他：胃穹蕗部粘膜 下腫湟（平滑筋腫）の十二指腸脱出例。胃と腸 $12: 1333-1337,1977$

8）小林成禎, 大島健次郎, 広澒 洋他: 胃 -十二指

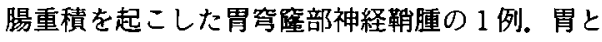
腸 $14: 1211-1215 ， 1979$

9）石原健二，久本信実，木原 㜴他：十二指腸球部 に嵌頓した胃Schwannoma の 1 例. Gas troenterol Endosc 23:320-326, 1981

10）朔 元則, 草場威稜夫, 納富昌徳他：十二指腸内 へ嵌頓した胃穹䆹部平滑筋腫の 1 例. 消外 4 : $1464-1467,1981$

11）布施好信, 福田新一郎, 内藤英二他：十二指腸に 脱出した胃体上部平滑筋腫の 1 例. Gastroenterol Endosc 25:1254-1258, 1983

12）石川隆尉, 鈴木良一, 浅田 学他：十二指腸へ嵌 頓した胃管薩部平滑筋腫の 1 例. 旭中病医報 $6: 395-398,1984$
13）大村良介, 永富裕二, 村上不二夫他：胃十二指腸 重積をおこした胃平滑筋芽細胞腫の 1 例. Gastroenterol Endosc 28:860, 1986

14）西浦和男, 荒川龍夫, 角田清志他：十二指腸球部 に嵌頓した胃体上部平滑筋腫の 1 例. 臨外 43 ： $1237-1240,1988$

15）大下裕夫, 田中千凱, 伊藤隆夫他：十二指腸に脱 出し，通過障害をきたした胃管璒部平滑筋肉腫の 1 例. 消外 $13: 1553-1557,1990$

16）神崎 司, 佐藤四三, 鍋山 晃他：石灰化を伴っ た胃体上部平滑筋腫の十二指腸球部に脱出した 1 例. 日消外会誌 $24 ： 1051-1055,1991$

17）善田貴裕, 増永高晴, 田口達哉他：胃体上部の平 滑筋腫により胃十二指腸重積を来した，いわゆる ball valve syndrome $の 1$ 例. 日消病会誌 91 : $1228-1233,1994$

18）吉田哲也，高見元做，藤本高義他：十二指腸球部 への嵌入を起こした胃体上部の隆起型早期胃癌の

1 例. Gastroenterol Endosc 35:70-77, 1993

19）矢後岳志, 治部達夫, 横皇徳行他：胃重積を起こ した胃穹䈃部平滑筋肉腫の 1 例。日外科系連会誌 $22: 929-933,1997$

20）佐々木厚博, 島買公義，佐竹賢仰他：十二指腸球 部に脱出した胃營廍部平滑筋肉腫の 1 例。日消病 会誌 $95: 233-237,1998$

21）高山智枚, 島野吉裕, 山口 晃他：十二指腸に嵌 頃した胃底部平滑筋肉腫の 1 例. 日消外会誌 $32: 2548-2552,1999$

22）黒川利雄：X線像による消化管診断学. 中山書店, 東京, 1975, p954

23) Hobb WH, Cohen SE: Gastroduodenal invagination due to a submucous lipoma of the stomach. Am J Surg 71 :505-518, 1946

24) Hallap G, Hakkal O, Cigtay S:Duodenal pseudotumor with ball-valve syndrome. South Med J $71: 1569-1570,1978$ 


\title{
A CASE OF HYPERPLASTIC POLYP IN THE UPPER PART OF THE STOMACH PROLAPSED INTO THE DUODENUM
}

\author{
Isamu HOSHINO, Matsuo NAGATA, Kazuo WATANABE, \\ Hiroshi YAMAMOTO, Kentaro TASAKI and Satoshi WATANABE \\ Department of Gastroenterological Surgery. Chiba Cancer Center
}

\begin{abstract}
A 50-year-old woman seen at another hospitl because of epigastralgia and melena and found to have an easily bleeding tumor of the stomach by an upper gastrointestinal endoscopic study was admitted to the hospital for further examinations and treatment. An upper gastrointestinal series and an endoscopic examination revealed a tumor arising from the upper part of stomach prolapsing into the duodenum and the tumor was moved back through the pylorus ring easily. And another like-O-II $c$ type tumor on the antrum was visualized. Their biopsy specimens were histologically hyperplastic polyp and poorly differentiated adenocarcinoma, respectively. A distal gastrectomy and tumor excision were performed.

Tumors of the stomach prolapsed into the duodenum are not so uncommon but the tumnor arising from the upper part of the stomach prolapsed into the duodenum like our case is relatively rare.
\end{abstract}

